STUDIA PRAWNO-EKONOMICZNE, T. CVI, 2018

PL ISSN 0081-6841; $\quad$ e-ISSN 2450-8179 $\quad$ s. 181-195

https://doi.org/10.26485/SPE/2018/106/11

\title{
Alicja BRODZKA*
}

\section{SKUTECZNOŚĆ UMÓW O WYMIANIE INFORMACJI PODATKOWYCH W RELACJACH Z PAŃSTWAMI STOSUJĄCYMI SZKODLIWĄ KONKURENCJĘ PODATKOWA}

\begin{abstract}
(Streszczenie)
Artykuł podejmuje tematykę umów o wymianie informacji podatkowych (TIEA) zawieranych przez Rzeczpospolitą Polską z tzw. krajami stosującymi szkodliwą konkurencję podatkową. Ze względu na fakt, iż porozumienia TIEA są relatywnie nowymi instrumentami w rzeczywistości nie tylko polskiej, ale również międzynarodowej, w badaniach podjęto próbę odpowiedzi na pytanie, czy umowy o wymianie informacji podatkowych są rzeczywiście stosowane w celach utrzymania międzynarodowych relacji z „krajami niewspółpracującymi”. Metodą analityczno-porównawczą zbadano aktualny stan prawny umów TIEA oraz jego wpływ na możliwość uzyskania informacji od administracji podatkowych terytoriów offshore. Na podstawie danych uzyskanych z Biura Wymiany Informacji Podatkowych w Koninie zanalizowano, czy uruchomione instrumenty prawne pozwalają Polsce na współpracę w omawianym zakresie. Późniejsze porównanie zebranych danych z informacjami uzyskanymi z administracji podatkowej Królestwa Niderlandów - kraju o znacznie dłuższej tradycji w wymianie informacji z terytoriami trzecimi - pozwoliło na dokonanie oceny efektywności wykorzystania polskich porozumień TIEA.
\end{abstract}

Słowa kluczowe: umowy o wymianie informacji podatkowych (TIEA); raje podatkowe; szkodliwa konkurencja podatkowa; międzynarodowe standardy przejrzystości i wymiany informacji podatkowych

Klasyfikacja JEL: F53, H26, H7, K34

* Dr, Uniwersytet Ekonomiczny we Wrocławiu, Wydział Nauk Ekonomicznych, Katedra Finansów; e-mail: alicja.brodzka@ue.wroc.pl 


\section{Wstęp}

Dynamika współczesnej gospodarki powoduje, że coraz większe znaczenie - zarówno dla administracji podatkowej, jak i dla podatnika - ma tempo i jakość gromadzonych informacji. Współcześnie obserwować można dynamiczny rozwój systemów przekazywania informacji we współpracy między administracjami podatkowymi różnych państw ${ }^{1}$. Na szczególną uwagę zasługują relacje $\mathrm{w}$ tym zakresie z tzw. krajami stosującymi szkodliwą konkurencję podatkową. Kraje te, o łagodnych systemach podatkowych, stosujące zachęty w celu przyciągnięcia zagranicznego kapitału, przez lata tajemnicę bankową traktowały jako warunek sine qua non dla swoich systemów, budząc tym samym wiele kontrowersji. $\mathrm{Na}$ arenie międzynarodowej wskazywano, iż szkodliwa konkurencja podatkowa ${ }^{2}$ powoduje tzw. erozję globalnej bazy opodatkowania. Tax Justice Network szacował wysokość aktywów zgromadzonych przez zamożne osoby fizyczne na terytoriach offshore na minimum 21 bln USD. Kwoty te, przy uwzględnieniu środków ulokowanych w takich konstrukcjach jak trusty, fundacje czy akcje na okaziciela, mogły wzrastać nawet do 32 bln USD. W konsekwencji kraje rezydencji zamożnego podatnika, nie mając informacji o jego zagranicznych aktywach, pozbawione były możliwości ich opodatkowania. Analizy wskazywały, iż opodatkowanie dochodu ze środków offshore przyniosłoby państwom rezydencji ich właścicieli niebagatelne wpływy w wysokości 190-280 mld USD ${ }^{3}$.

1 B. Brzeziński, Relacje między administracja podatkowa a podatnikami - od konfrontacji do wspótpracy, w: P. Borszowski, A. Huchla, E. Rutkowska-Tomaszewska (red.), Podatnik versus organ podatkowy, Studia Finansowoprawne, nr 2, Prace Naukowe Wydziału Prawa, Administracji i Ekonomii Uniwersytetu Wrocławskiego, Wrocław 2011, s. 39.

2 Według rady ECOFINu, szkodliwa konkurencja podatkowa ma miejsce, gdy: (a) preferencyjne rozwiązania są wprowadzane wyłącznie w celu przyciągnięcia zagranicznego kapitału, dotychczas podlegającego opodatkowaniu na innym terytorium, (b) zastosowanie mają tzw. praktyki ring fencing zakładające brak możliwości korzystania z preferencyjnego systemu podatkowego w warunkach lokalnych, (c) stosowane korzyści podatkowe nie mają podłoża ekonomicznego - są gwarantowane niezależnie od tego, czy na danym terytorium prowadzona jest rzeczywista aktywność gospodarcza, (d) zyski uznawane za podstawę opodatkowania są szacowane w sposób odbiegający od ogólnie przyjętych międzynarodowych standardów, (e) brak jest przejrzystości w sferze podatkowej (więcej w: Conclusions of the Council of Economics and Finance Ministers (ECOFIN) of 1 December 1997 concerning taxation policy, Komisja Europejska 1998/98/C 2/01).

3 Tax us if you can, Tax Justice Network, $2^{\text {nd }}$ Edition, 28.11.2012, s. 3. 
Malejące przychody podatkowe oraz globalny kryzys finansowy stały się katalizatorami dla inicjatyw mających na celu osłabienie znaczenia terytoriów „niewspółpracujących”. Podjęte działania zmierzały do zwiększenia przejrzystości międzynarodowych przepływów finansowych, a także umożliwienia wymiany informacji pomiędzy administracjami podatkowymi poszczególnych państw.

W 2000 r. OECD opublikowało czarną listę wymieniającą 35 rajów podatkowych; 47 kolejnych terytoriów określono mianem ,potencjalnie szkodliwych reżimów podatkowych". Warunkiem usunięcia danego kraju z czarnej listy miała być deklaracja współpracy w kierunku przejrzystości i efektywnej wymiany informacji podatkowych. Zgodnie ze standardami przyjętymi przez OECD za „współpracującą" jurysdykcję podatkową można było uznać terytorium, które zawarło co najmniej 12 porozumień, na podstawie których możliwa była międzynarodowa wymiana informacji podatkowej ${ }^{4}$.

Opisana inicjatywa zmusiła „terytoria niewspółpracujące” do stopniowej zmiany nastawienia i przyjęcia proponowanych (narzucanych) rozwiązań. Kraje wymienione na czarnej liście OECD protestowały przeciwko praktykom, podnosząc, iż ich sektory finansowe charakteryzują się wysoką stabilnością, a stosowane procedury zapewniają bezpieczeństwo obrotu finansowego. Niemniej jednak odium „publicznego napiętnowania” (naming and shaming) okazało się sankcją na tyle dotkliwą, iż w ciągu kolejnych lat „terytoria niewspółpracujące” zaczęły sukcesywnie podejmować zobowiązania przyjęcia międzynarodowych standardów podatkowych w celu usunięcia ich z czarnej listy OECD.

By uniknąć oskarżeń o wspieranie uchylania się od opodatkowania i ułatwianie prania brudnych pieniędzy, wiele jurysdykcji uznawanych za raje podatkowe rozpoczęło negocjacje tzw. umów o wymianie informacji podatkowych z głównymi państwami Grupy G20 (a także z innymi „terytoriami niewspółpracującymi”). W konsekwencji świat odnotował gwałtowny wzrost liczby porozumień stanowiących prawną podstawę do transgranicznego wnioskowania o udostępnianie informacji podatkowych, a w 2009 r. z czarnej listy OECD usunięte zostały ostatnie terytoria - Andora, Lichtenstein i Monako. W większości przypadków dochodziło do podpisania bilateralnych umów o wymianie informacji podatkowych (Tax Information Exchange Agreements - TIEA).

4 Towards Global Tax Cooperation, Report to the 2000 Ministerial Council Meeting and Recommendations by the Committee on Fiscal Affairs: Progress in Identifying and Eliminating Harmful Tax Practices, OECD 2000, s. 17. 


\section{Umowy o wymianie informacji podatkowych (TIEA)}

W zamierzeniu grupy roboczej OECD priorytetowym celem porozumień TIEA miało być promowanie międzynarodowej współpracy w sprawach podatkowych poprzez umożliwienie wymiany informacji pomiędzy administracjami odrębnych krajów. W trakcie prac nad walką ze szkodliwymi praktykami podatkowymi OECD opracowało międzynarodowy standard wymiany informacji. Wymagał on od państw wymiany danych na żądanie w zakresie wszystkich spraw podatkowych dla celów administracji i wykonywania lokalnych przepisów prawa - co ważne, również przez banki i inne instytucje finansowe, które dotychczas nie zgadzały się na udostępnianie informacji o swoich klientach. Standard OECD objął też ochronę przekazywanych danych ${ }^{5}$.

Międzynarodowy standard wymiany informacji opracowany przez OECD został następnie uwzględniony w roku 2002 przy tworzeniu tzw. modelowej umowy TIEA. Modelowa umowa TIEA, sama nie będąc instrumentem wiążącym, zaczęła stanowić wzorzec dla negocjacji poszczególnych bilateralnych umów o wymianie informacji podatkowych. W konsekwencji podpisywane porozumienia TIEA stały się instrumentami o zestandaryzowanej konstrukcji.

Umowa TIEA umożliwia wymianę informacji, które mogą być istotne do celów stosowania i egzekwowania krajowych przepisów podatkowych stron porozumienia, w tym dla określenia, wymiaru i poboru podatku, dla windykacji i egzekucji zaległości podatkowych, a także dochodzeń w sprawach podatkowych. Dane mogące być przedmiotem transferu obejmują m.in. informacje o strukturze własnościowej podmiotów, prawnych i rzeczywistych właścicielach spółek, spółkach osobowych, publicznych zbiorowych programach inwestycyjnych, funduszach powierniczych, trustach, fundacjach i innych osobach - łącznie z informacjami o wszystkich osobach, które w strukturze tworzą łańcuch właścicielski. Porozumienie TIEA nakłada na stronę wnioskującą obowiązek wykazania istotnego znaczenia danej informacji dla wniosku (foreseeably relevance). Państwo występujące o udzielenie informacji musi przedstawić dane identyfikujące osobę, w sprawie której prowadzone jest postępowanie, okres, którego dotyczą wnioskowane informacje, rodzaj żądanej informacji, cel podatkowy, dla którego informacje są wnioskowane, a także nazwisko (nazwę) i adres każdej osoby, która może być w posiadaniu żądanych informacji (jeśli jest znane) ${ }^{6}$.

5 E. Matyszewska, Terytoria uznawane za raje podatkowe wprowadzaja zmiany, Dziennik Gazeta Prawna, 17.05.2010.

6 OECD, Agreement on the Exchange of Information on Tax Matters, OECD Global Forum Working Group on Effective Exchange of Information, 2012. 


\section{Polska wymiana informacji podatkowych z krajami stosującymi szkodliwą konkurencję podatkową}

Polska, jako kraj OECD, również podjęła działania nakierowane na rozwój międzynarodowej współpracy administracyjnej w sprawach podatkowych. W niektórych przypadkach zdecydowano się na rozszerzenie funkcjonujących już umów o unikaniu podwójnego opodatkowania o pełną klauzulę wymiany informacji podatkowych $\mathrm{z}$ informacją znajdującą się $\mathrm{w}$ posiadaniu instytucji finansowych lub banków włącznie. Ten przypadek dotyczył jednakże państw, z którymi utrzymywano wcześniej długoterminowe relacje gospodarcze.

W relacjach z krajami stosującymi szkodliwą konkurencję podatkową, które nie miały wcześniej podpisanych dwustronnych porozumień o unikaniu podwójnego opodatkowania, wykorzystano umowy o wymianie informacji podatkowych. Począwszy od 2009 r., Polska rozpoczęła negocjacje zmierzające do objęcia bazą traktatową terytoriów ,niewspółpracujących”. Pierwsze porozumienia TIEA zostały podpisane w 2011 r. z Wyspami Normandzkimi: Jersey, Guernsey, a także z Wyspą Man. Rok 2012 przyniósł 4 umowy o wymianie informacji podatkowych, z Andorą, Grenadą, San Marino i Wspólnotą Dominiki. W roku 2013 podpisano kolejnych 7 umów: z Belize, Bermudami, Brytyjskimi Wyspami Dziewiczymi, Gibraltarem, Kajmanami, Liberią i Wspólnotą Bahamów. W sumie Rzeczpospolita Polska zawarła 14 umów o wymianie informacji podatkowych, przy czym należy zwrócić uwagę na fakt, iż w trzech przypadkach (Belize, Grenada i Liberia) porozumienia te do dnia dzisiejszego nie weszły w życie.

Wymiana informacji na żądanie na podstawie opisywanych instrumentów po raz pierwszy stała się realna pod koniec $2011 \mathrm{r}$. (na mocy porozumienia z Wyspą Man), od marca 2015 r. taka możliwość występuje w przypadku wszystkich 11 terytoriów, będących stroną (ratyfikowanych) umów o wymianie informacji podatkowych. W tabeli 1 przedstawiono wykaz wszystkich państw, z którymi Rzeczpospolita Polska zawarła umowy TIEA, wraz z datą podpisania i obowiązywania porozumienia, a także miejscem publikacji w Dzienniku Ustaw.

TABELA 1: Umowy o wymianie informacji podatkowych podpisane przez Rzeczpospolita Polska

\begin{tabular}{|l|c|c|c|}
\hline \multicolumn{1}{|c|}{ Państwo } & Data podpisania & $\begin{array}{c}\text { Obowiązuje } \\
\text { od }\end{array}$ & $\begin{array}{c}\text { Miejsce publikacji } \\
\text { Dz.U. }\end{array}$ \\
\hline Andora & 15.06 .2012 & 01.01 .2014 & 2013 , poz. 1602 \\
\hline Belize & 16.05 .2013 & - & - \\
\hline
\end{tabular}




\begin{tabular}{|l|c|c|c|}
\hline \multicolumn{1}{|c|}{ Państwo } & Data podpisania & $\begin{array}{c}\text { Obowiązuje } \\
\text { od }\end{array}$ & $\begin{array}{c}\text { Miejsce publikacji } \\
\text { Dz.U. }\end{array}$ \\
\hline Bermudy & 25.11 .2013 & 15.03 .2015 & 2015, poz. 223 \\
\hline $\begin{array}{l}\text { Brytyjskie Wyspy } \\
\text { Dziewicze }\end{array}$ & 28.11 .2013 & 01.01 .2015 & 2014, poz. 1715 \\
\hline Gibraltar & 31.01 .2013 & 05.12 .2013 & 2014, poz. 313 \\
\hline Grenada & 19.07 .2012 & - & - \\
\hline Guernsey & 06.12 .2011 & 01.11 .2012 & 2012, poz. 1050 \\
\hline Jersey & 02.12 .2011 & 01.11 .2012 & 2012, poz. 1057 \\
\hline Kajmany & 29.11 .2013 & 11.12 .2014 & 2015, poz. 185 \\
\hline Liberia & 07.08 .2013 & - & - \\
\hline San Marino & 31.03 .2012 & 28.02 .2013 & 2013, poz. 453 \\
\hline Wspólnota Bahamów & 28.06 .2013 & w pełni & 2014, poz. 1343 \\
\hline Wspólnota Dominiki & 10.07 .2012 & - & - \\
\hline Wyspa Man & 07.03 .2011 & 27.11 .2011 & $2011, \mathrm{nr} 283$, poz. 1665 \\
\hline
\end{tabular}

Ź ró d ł o: Ministerstwo Finansów, http://www.finanse.mf.gov.pl; stan na 01.02.2017 r.

Zawarcie umów o wymianie informacji z „terytoriami niewspółpracującymi”, oprócz instrumentu wymiany informacji dla organów podatkowych, wiąże się również z korzyściami dla podatników. Konsekwencją podpisania porozumienia TIEA oraz efektywnego jego stosowania jest usunięcie danej jurysdykcji z list zawartych w rozporządzeniach Ministra Finansów w sprawie krajów i jurysdykcji stosujących szkodliwe praktyki podatkowe. Tym samym znosi konieczność sporządzania dodatkowej dokumentacji w przypadku zawierania transakcji z podatnikami mającymi siedzibę w takim kraju. Rzeczywiście, podpisanie porozumień TIEA zaskutkowało ogłoszeniem w 2015 r. skróconej listy terytoriów stosujących szkodliwą konkurencję podatkową. Obecnie na polskiej czarnej liście znajduje się 31 krajów?

Ze względu na fakt, iż porozumienia TIEA są relatywnie nowymi instrumentami w rzeczywistości nie tylko polskiej, ale również międzynarodowej

7 Rozporządzenie Ministra Finansów z dnia 23 kwietnia 2015 r. w sprawie określenia krajów i terytoriów stosujących szkodliwą konkurencję podatkową w zakresie podatku dochodowego od osób fizycznych (Dz.U. z 2015 r., poz. 599); Rozporządzenie Ministra Finansów z dnia 23 kwietnia 2015 r. w sprawie określenia krajów i terytoriów stosujących szkodliwą konkurencję podatkową w zakresie podatku dochodowego od osób prawnych (Dz.U. z 2015 r., poz. 600). Wcześniejsze Rozporządzenia Ministra Finansów w sprawie określenia krajów i terytoriów stosujących szkodliwą konkurencję podatkową z 2013 r. zawierało 37 jurysdykcji. 
w badaniach podjęto próbę odpowiedzi na pytanie, czy umowy o wymianie informacji podatkowych są rzeczywiście używane w celach uzyskania informacji od terytoriów stosujących szkodliwą konkurencję podatkową, a także, czy stanowią efektywne narzędzie $\mathrm{w}$ walce $\mathrm{z}$ uchylaniem się od opodatkowania i przyczyniają się do zwiększenia transparentności finansowej.

W celu odpowiedzi na pytanie badawcze złożono zapytanie do Biura Wymiany Informacji Podatkowych w Koninie pełniącego funkcję Centralnego Biura Łącznikowego (central liaison office), odpowiedzialnego za kontakty i wymianę informacji z administracją podatkowo-skarbową innych państw, a także umocowanego do świadczenia wzajemnej pomocy przy dochodzeniu podatków, należności celnych i innych należności pieniężnych ${ }^{8}$.

W odpowiedzi na wniosek o udostępnienie informacji publicznej uzyskano dane o wykorzystaniu umów TIEA, których stroną jest Rzeczpospolita Polska. Dane te zaprezentowano w tabeli 2.

TABELA 2: Wymiana informacji na podstawie umów TIEA: wnioski o informacje podatkowa wystane przez Polskę (podatki bezpośrednie), lata 2011-2015

\begin{tabular}{|l|c|c|c|c|c|}
\hline \multicolumn{1}{|c|}{ Państwo } & 2011 & 2012 & 2013 & 2014 & 2015 \\
\hline Andora & - & - & - & - & - \\
\hline Bermudy & - & - & - & - & - \\
\hline Brytyjskie Wyspy Dziewicze & - & - & - & - & - \\
\hline Gibraltar & - & - & - & 1 & 10 \\
\hline Guernsey & - & - & - & - & - \\
\hline Jersey & - & - & - & 1 & - \\
\hline Kajmany & - & - & - & - & 2 \\
\hline San Marino & - & - & - & - & - \\
\hline Wyspa Man & - & - & - & - & - \\
\hline Wspólnota Bahamów & - & - & - & - & - \\
\hline
\end{tabular}

Ź ró d ł o: Biuro Wymiany Informacji Podatkowych w Koninie, kwiecień 2016.

$\mathrm{Z}$ analizowanych danych wynika, iż umowy o wymianie informacji podatkowych stanowią instrument nowy, który zaczął być wykorzystywany przez Rzeczpospolitą Polską bardzo niedawno. Rzeczywiście, dopiero w 2014 r. doszło do wystosowania dwóch wniosków: do administracji podatkowej Jersey

8 Załacznik nr 3 do Regulaminu Organizacyjnego Izby Skarbowej w Poznaniu z 2015 r.: Regulamin Organizacyjny Biura Wymiany Informacji Podatkowych w Koninie, Izba Skarbowa w Poznaniu, kwiecień 2015. 
(porozumienie TIEA obowiązujące od listopada 2012) i Gibraltaru (TIEA obowiązujące od grudnia 2013 r.); w 2015 r. ogólna liczba złożonych wniosków wyniosła 12 , z czego 2 prośby wysłano na Kajmany (umowa weszła w życie w grudniu 2014 r.), pozostałych 10 zaś do Gibraltaru.

W wywiadzie pogłębionym przedstawiciele Biura Wymiany Informacji Podatkowych w Koninie podkreślili, iż umowy TIEA w większości weszły w życie dopiero po roku 2013. Uzasadniając niewielką do tej pory liczbę złożonych wniosków o informacje, wskazywali na czas potrzebny do przygotowania odpowiednich procedur. Podkreślono także, iż w latach wcześniejszych nie była prowadzona żadna wymiana informacji na wniosek między Rzeczpospolitą Polską a terytoriami stosującymi szkodliwą konkurencję podatkową. Również w badanym okresie (2011-2015) nie doszło do żadnych relacji w zakresie wymiany informacji podatkowych na żądanie $\mathrm{z}$ terytoriami znajdującymi się na polskiej „czarnej liście”, z którymi strona polska nie zawarła umowy o wymianie informacji podatkowych. W konsekwencji można uznać, iż porozumienia TIEA wypełniły lukę w relacjach $\mathrm{z}$ „terytoriami niewspółpracującymi”. Wydaje się, iż przyszłość przyniesie częstsze i bardziej aktywne wykorzystanie umów o wymianie informacji podatkowych. Dla pełnej oceny efektywności badanych instrumentów zdecydowano się dokonać analizy porównawczej powoływania się na umowy TIEA w relacjach z krajami o rozwiniętej poufności bankowej, na przykładzie Królestwa Niderlandów - kraju o długoletniej tradycji współpracy administracyjnej w obszarze wymiany informacji podatkowych.

\section{Doświadczenia Królestwa Niderlandów w wykorzystaniu umów o wymianie informacji podatkowych}

Holenderska sieć 29 porozumień TIEA potwierdza ważność zagadnienia międzynarodowej wymiany informacji dla administracji podatkowej Królestwa Niderlandów. Umowy o wymianie informacji podatkowych były zawierane przez Holandię wcześniej niż przez Polskę, bo w latach 2005-2012. Pierwsze porozumienia weszły w życie w roku 2006 (Wyspa Man) i 2008 (Jersey, Guernsey), na większość umów TIEA można było się w pełni powoływać od okresu 2011/2012. Dwie umowy (z San Marino i Urugwajem) wciąż nie weszły w życie. W tabeli 3 zebrano informacje na temat holenderskich umów TIEA, dacie ich zawarcia, a także dacie wejścia w życie. 
TABELA 3: Umowy o wymianie informacji podatkowych podpisane przez Królestwo Niderlandów

\begin{tabular}{|l|c|c|}
\hline \multicolumn{1}{|c|}{ Państwo } & Data podpisania & Obowiązuje od \\
\hline Andora & 06.11 .2009 & 01.01 .2011 \\
\hline Anguilla & 22.07 .2009 & 01.05 .2011 \\
\hline Antigua i Barbuda & 02.09 .2009 & 23.02 .2010 \\
\hline Belize & 04.02 .2010 & 01.01 .2011 \\
\hline Bermudy & 08.06 .2009 & 01.02 .2010 \\
\hline Brytyjskie Wyspy Dziewicze & 11.09 .2009 & 01.07 .2013 \\
\hline Costa Rica & 29.03 .2011 & 01.07 .2012 \\
\hline Gibraltar & 23.04 .2010 & 01.12 .2011 \\
\hline Grenada & 18.02 .2010 & 20.01 .2012 \\
\hline Guernsey & 25.04 .2008 & 11.04 .2009 \\
\hline Jersey & 20.06 .2007 & 01.03 .2008 \\
\hline Kajmany & 08.07 .2009 & 29.12 .2009 \\
\hline Liberia & 27.05 .2010 & 01.06 .2012 \\
\hline Lichtenstein & 10.11 .2009 & 01.12 .2010 \\
\hline Monako & 11.01 .2010 & 01.12 .2010 \\
\hline Montserrat & 10.12 .2009 & 01.12 .2011 \\
\hline Saint Kitts i Nevis & 02.09 .2009 & 29.11 .2010 \\
\hline Samoa & 14.09 .2009 & 02.03 .2012 \\
\hline San Marino & 27.01 .2010 & - \\
\hline Santa Lucia & 12.02 .2009 & 31.03 .2011 \\
\hline Seszele & 04.08 .2010 & 01.09 .2012 \\
\hline Św. Vincent i Grenadyny & 01.09 .2009 & 21.03 .2011 \\
\hline Turks i Caicos & 22.07 .2009 & 01.05 .2011 \\
\hline Urugwaj & 24.10 .2012 & - \\
\hline Wspólnota Bahamów & 04.12 .2009 & 01.03 .2012 \\
\hline Wspólnota Dominiki & 11.05 .2010 & 24.07 .2006 \\
\hline Wyspy Cooka & 12.10 .2005 & \\
\hline Wyspa Man & 14.05 .2010 & \\
\hline Wyspy Marshalla & & \\
\hline & 23.10 .2009 & \\
\hline
\end{tabular}

Ź r ó d ł o: http://www.EoI-tax.org/jurisdictions/NL\#agreements; stan na 31.12.2016 r.

W odpowiedzi na pytanie o współpracę w zakresie wymiany informacji podatkowych na żądanie, przy powołaniu się na umowy TIEA, holenderskie Centralne Biuro Łącznikowe udostępniło dane statystyczne dotyczące 
wniosków wysłanych przez Królestwo Niderlandów do krajów trzecich w latach 2010-2014. Szczegółowe zestawienie zostało przedstawione w tabeli 4.

TABELA 4: Wymiana informacji na podstawie umów TIEA: wnioski o informacje podatkowa wystane przez Holandię (podatki bezpośrednie), lata 2010-2014

\begin{tabular}{|l|c|c|c|c|c|}
\hline \multicolumn{1}{|c|}{ Państwo } & 2010 & 2011 & 2012 & 2013 & 2014 \\
\hline Andora & - & - & - & - & - \\
\hline Anguilla & - & - & 4 & - & 1 \\
\hline Antigua i Barbuda & - & - & - & - & - \\
\hline Belize & - & - & 1 & 1 & - \\
\hline Bermudy & - & - & - & - & - \\
\hline Brytyjskie Wyspy Dziewicze & - & - & - & - & 4 \\
\hline Costa Rica & - & - & - & - & - \\
\hline Dominika & - & - & - & - & - \\
\hline Gibraltar & - & - & 4 & 2 & 4 \\
\hline Grenada & - & - & - & - & - \\
\hline Guernsey & 4 & 2 & 1 & 4 & 3 \\
\hline Jersey & 3 & 2 & 4 & 6 & 10 \\
\hline Kajmany & - & - & 4 & 0 & - \\
\hline Liberia & - & - & - & - & - \\
\hline Lichtenstein & - & 7 & 21 & 3 & 2 \\
\hline Monako & - & - & 1 & 3 & 0 \\
\hline Montserrat & - & - & - & - & - \\
\hline Saint Kitts i Nevis & - & - & - & - & - \\
\hline Santa Lucia & - & - & - & - & - \\
\hline Samoa & - & - & - & - & - \\
\hline San Marino & - & - & - & - & - \\
\hline Św. Vincent i Grenadyny & - & - & - & - & - \\
\hline Seszele & - & - & - & - & - \\
\hline Turks i Caicos & - & - & - & - & - \\
\hline Urugwaj & - & - & - & - & - \\
\hline Wspólnota Bahamów & - & - & - & - & - \\
\hline Wyspa Man & - & - & - & - \\
\hline Wyspy Cooka & - & - & & \\
\hline Wyspy Marshalla & - & - & - & - & - \\
\hline & - & - & - & - & - \\
\hline
\end{tabular}

Źr ó d ł o: Holenderskie Centralne Biuro Łącznikowe, Almelo, kwiecień 2016.

Wyniki zestawienia wskazują na szerokie wykorzystanie porozumień TIEA do uzyskiwania informacji podatkowych z „terytoriów niewspółpracujących” przez administrację podatkową Holandii. Państwo to rozpoczęło współpracę 
z terytoriami o rozwiniętej tajemnicy bankowej znacznie wcześniej od Polski - w 2010 r. wystapiło z wnioskami o udzielenie informacji do administracji podatkowych wysp Jersey i Guernsey (odpowiednio 4 i 3 wnioski). W następnych latach współpraca z Wyspami Normandzkimi w zakresie wymiany danych podatkowych utrzymała się na w miarę stabilnym poziomie (od 2 do 6 wniosków rocznie, z wyjątkiem roku 2014, gdy do Guernsey skierowano 10 wniosków). Stałe relacje utrzymywano również z Księstwem Lichtensteinu, do którego w roku 2012 skierowano 7 wniosków, rok później 21, w kolejnych latach zaś odpowiednio 3 i 2. Kolejne jurysdykcje, z którymi Królestwo Niderlandów stale współpracuje w zakresie uzyskiwania informacji o swoich podatnikach, to Wyspa Man (1-2 wnioski rocznie w latach 2011-2014), Gibraltar (w latach 2012, 2013, 2014 odpowiednio 4, 2 i 4 wnioski rocznie), Monako (1 i 3 wnioski wysłane w latach 2012 i 2013). Prośby o udostępnienie informacji podatkowych wysyłane są również do Anguilli (4 w 2012 i 1 w 2014), do Belize (po jednym w roku 2012 i 2013), na Kajmany (4 w 2012) i Wyspy Marshalla (7 w 2012 r). Wejście w życie ostatniej umowy TIEA (lipiec 2013) umożliwiło rozpoczęcie relacji z Brytyjskimi Wyspami Dziewiczymi; w konsekwencji w 2014 r. przygotowano i wysłano 4 wnioski o informacje.

W latach 2010-2014 Holandia wysłała w sumie 113 wniosków o informacje na podstawie badanych umów, przy czym maksimum zapytań o dane podatkowe (48) przypadło na rok 2012; znaczący wzrost ilości wysłanych wniosków był spowodowany wejściem w życie większości porozumień TIEA. Zaprezentowane dane potwierdzają, iż Królestwo Niderlandów ma długą tradycję w wykorzystaniu umów TIEA w procesie międzynarodowej wymiany informacji podatkowych. W wywiadzie pogłębionym przedstawiciele Centralnego Biura Łącznikowego Holandii dodatkowo podkreślili dobrą współpracę z władzami podatkowymi Wysp Normandzkich, a także Lichtensteinu. Holandia, wychodząc wprost z założenia, że „chodzi głównie o pieniądze i kontakty”, podtrzymuje relacje z władzami podatkowymi krajów trzecich; dokłada starań, by wszystkie wnioski o udzielenie informacji były przygotowane w sposób rzetelny i zawsze zawierały solidne uzasadnienie. Dodatkowo wnioski sporządzane są na specjalnych, zestandaryzowanych formularzach - wszystkie te wymienione elementy ułatwiają cały proces i wpływają na skrócenie czasu oczekiwania na dane podatkowe.

W historii wymiany informacji na bazie umów TIEA nie było przypadku odmowy udzielenia informacji; nie odnotowano także żadnych większych problemów w całym procesie współpracy z terytoriami trzecimi. Holenderskie władze podatkowe zwykle uzyskują wymagane informacje za darmo, tylko w jednym, szczególnie skomplikowanym przypadku doszło do zwrotu kosztów uzyskania władzom podatkowym kraju będącego adresatem wniosku o dane podatkowe. 


\section{Zakończenie}

Aktywna polityka OECD w ostatnich latach oraz działania podejmowane przez kraje G20 przyczynily się do zdecydowanej zmiany stanowiska większości krajów świata $w$ zakresie wymiany informacji podatkowych oraz tajemnicy bankowej. Wypracowano standardy OECD w zakresie wymiany informacji, powstała Modelowa Umowa OECD o wymianie informacji dla celów podatkowych. Do chwili obecnej wszystkie kraje świata objęte tzw. czarną listą OECD zdecydowały się podjąć współpracę w zakresie wymiany informacji podatkowych i implementować międzynarodowe standardy, zarówno w bazie traktatowej, jak i w prawie wewnętrznym 9 .

Zaprezentowane dane, a także późniejsza pogłębiona analiza jakościowa zagadnienia, przeprowadzona za pomocą wywiadów z przedstawicielami administracji podatkowej Rzeczpospolitej Polskiej wskazały, iż w latach poprzedzających zawarcie umów TIEA nie istniały żadne relacje w zakresie wymiany informacji podatkowych z krajami stosującymi szkodliwą konkurencję podatkową i odmawiającymi udzielania informacji ze względu na zasadę poufności bankowej. Umowy o wymianie informacji, stopniowo negocjowane i podpisywane, stanowiły zatem dla administracji podatkowej pierwszą w historii podstawę prawną do rozpoczęcia relacji (w tym zakresie) z państwami „niewspółpracującymi”.

Niezależnie od niewielkiej liczby złożonych do chwili obecnej wniosków o wymianę informacji podatkowych należy przytoczyć ocenę, iż porozumienia TIEA zawierane przez Polskę okazały się skutecznym instrumentem, przyczyniającym się do poprawy międzynarodowej współpracy podatkowej. Ze względu na standaryzację zawartych umów wnioski przygotowywane przez administrację podatkową zawierają wszystkie niezbędne elementy, są również dobrze uzasadniane. Sprawia to, iż w badanym okresie nie miała miejsca odmowa realizacji żadnego $\mathrm{z}$ wniosków przetworzonych $\mathrm{w}$ ramach porozumień TIEA.

Przedstawiciele administracji podatkowej wskazują również na istotny element uczenia się - sukcesy związane z wykorzystaniem analizowanych instrumentów powodują większą pewność siebie urzędników, którzy w konsekwencji posługują się nimi dużo chętniej i częściej. Niebagatelne znaczenie ma także nawiązanie i późniejsze podtrzymywanie relacji z administracjami krajów

9 Departament Polityki Podatkowej Ministerstwa Finansów, 2010, Wspótpraca administracji podatkowych $w$ zakresie międzynarodowej wymiany informacji podatkowych, Biuletyn Skarbowy, 01.06.2010/3. 
trzecich będących odbiorcami zapytań. Dochodzi tu do efektu synergii: kraj wnioskujący nabywa doświadczenia w sporządzaniu dobrze udokumentowanych próśb o wymianę informacji, terytoria otrzymujące wnioski (nie tylko od strony polskiej, ale również od innych krajów) przestają się opierać i zaczynają traktować współpracę w zakresie wymiany informacji podatkowych jako standardowy element rzeczywistości, a nie jako czynnik grożący utracie ich pozycji konkurencyjnej.

$\mathrm{Na}$ uwagę zasługuje również opcja czerpania z doświadczeń innych krajów unijnych, szczególnie tych o dłuższej tradycji wymiany informacji z terytoriami „niewspółpracującymi”. Przykładem jest Królestwo Niderlandów znane ze skuteczności działania administracji podatkowej. Dane uzyskane z Centralnego Biura Łącznikowego Holandii i ich historyczna analiza dowodzą pewnej prawidłowości: po początkowym okresie „rozruchu” następuje wzrost ilości zapytań o informacje składanych przy powoływaniu się na porozumienia TIEA. Wydaje się, że Polska będzie podążać podobną ścieżką.

Analizy aktywności holenderskiej administracji podatkowej okazują się przydatne nie tylko ze względu na możliwość dokonania porównań w czasie. Na linii Polska - Holandia dochodzi również do aktywnej wymiany doświadczeń. Przykładem może być wizyta studyjna przedstawicieli Pierwszego Urzędu Skarbowego w Opolu w Centralnym Urzędzie Skarbowym w Utrechcie, do jakiej doszło w 2016 r. Celem wizyty było poznanie podejmowanych przez holenderską administrację podatkową działań zmierzających do poprawy efektywności kontroli podatkowych oraz zwiększenia skuteczności typowania podmiotów do kontroli ${ }^{10}$.

Bezpośredni kontakt z przedstawicielami zagranicznych urzędów skarbowych i centralnych organów podatkowych pozwala nie tylko na wymianę doświadczeń i zapoznanie się z nowoczesnymi standardami działania. Przedstawiciele administracji podatkowych wskazują również na kolejny istotny element: zmianę sposobu myślenia, stopniowe „wychodzenie” poza struktury pojedynczej organizacji i kierowanie się w stronę międzynarodowej współpracy. Dokonująca się ewolucja może w przyszłości dodatkowo wzmocnić działania zmierzające do przeciwdziałania oszustwom podatkowym. Porozumienia TIEA również mogą się wydatnie przyczynić do poprawy międzynarodowej współpracy administracyjnej w sprawach podatkowych.

10 Opolscy skarbowcy z wizyta w Holandii, Pierwszy Urząd Skarbowy w Opolu, Aktualności, 24.08.2016, www.opole.apodatkowa.gov.pl; stan na 01.20.2017 r. 


\section{Bibliografia}

\section{Akty prawne}

Rozporządzenie Ministra Finansów z dnia 23 kwietnia 2015 r. w sprawie określenia krajów i terytoriów stosujących szkodliwą konkurencję podatkową w zakresie podatku dochodowego od osób fizycznych (Dz.U. z 2015 r., poz. 599).

Rozporządzenie Ministra Finansów z dnia 23 kwietnia 2015 r. w sprawie określenia krajów i terytoriów stosujących szkodliwą konkurencję podatkową $\mathrm{w}$ zakresie podatku dochodowego od osób prawnych (Dz.U. z 2015 r., poz. 600).

\section{Opracowania}

Brzeziński Bogumil, Relacje między administracja podatkowa a podatnikami - od konfrontacji do wspótpracy, w: Paweł Borszowski, Andrzej Huchla, Edyta Rutkowska-Tomaszewska (red.), Podatnik versus organ podatkowy, Studia Finansowoprawne, nr 2, Prace Naukowe Wydziału Prawa, Administracji i Ekonomii Uniwersytetu Wrocławskiego, Wrocław 2011.

Code of Conduct for Business Taxation: Tax Measures Covered, w: Conclusions of the Council of Economics and Finance Ministers (ECOFIN) of 1 December 1997 concerning taxation policy, Komisja Europejska 1998/98/C 2/01.

Departament Polityki Podatkowej Ministerstwa Finansów, 2010, Wspótpraca administracji podatkowych w zakresie międzynarodowej wymiany informacji podatkowych, Biuletyn Skarbowy 01.06.2010/3.

Matyszewska Ewa, Terytoria uznawane za raje podatkowe wprowadzaja zmiany, Dziennik Gazeta Prawna, 17.05.2010.

OECD, Agreement on the Exchange of Information on Tax Matters, OECD Global Forum Working Group on Effective Exchange of Information, 2012.

Tax us if you can, $2^{\text {nd }}$ Edition, Tax Justice Network, 28.11.2012.

Towards Global Tax Cooperation, Report to the 2000 Ministerial Council Meeting and Recommendations by the Committee on Fiscal Affairs: Progress in Identifying and Eliminating Harmful Tax Practices, OECD 2000.

Załacznik nr 3 do Regulaminu Organizacyjnego Izby Skarbowej w Poznaniu z 2015 r:: Regulamin Organizacyjny Biura Wymiany Informacji Podatkowych w Koninie, Izba Skarbowa w Poznaniu, kwiecień 2015.

\section{Strony internetowe}

Opolscy skarbowcy z wizyta w Holandii, Pierwszy Urząd Skarbowy w Opolu, Aktualności, 24.08.2016, www.opole.apodatkowa.gov.pl; stan na 01.20.2017 r.

Wykaz umów o wymianie informacji w sprawach podatkowych, http://www.finanse.mf.gov.pl; stan na 01.02.2017 r.

Netherlands has exchange of information relationships with 126 jurisdictions through 97 DTCs and 29 TIEAs, http://www.EoI-tax.org/jurisdictions/NL\#agreements; stan na 31.12.2016 r. 
Alicja BRODZKA

\title{
THE EFFECTIVENESS OF TAX INFORMATION EXCHANGE AGREEMENTS IN RELATIONS WITH UNCOOPERATIVE TERRITORIES
}

\author{
( Sum mary)
}

The paper deals with the subject of tax information exchange agreements (TIEAs) concluded by Poland with so called "uncooperative territories" - e.g. countries that use harmful tax competition. As TIEAs are a relatively new measure, the author attempted to answer the question whether TIEAs really helped Poland to increase the transparency and strengthened the international cooperation in the tax information exchange area. The examination of the data obtained from Polish Central Liaison Office shows whether TIEAs are commonly used by Polish tax authorities. The comparison of the Polish results with the experience of Netherlands - a country with a much longer tradition in the exchange of information with third territories - allows for evaluation of the effectiveness of the use of Polish TIEA agreements.

Keywords: tax information exchange agreements (TIEAs); tax havens; harmful tax competition; international standards of transparency and exchange of tax information 